\title{
Carboxylic acids in the rural continental atmosphere over the eastern United States during the Shenandoah Cloud and Photochemistry Experiment
}

\section{Citation}

Talbot, Robert W., Byard W. Mosher, Brian G. Heikes, Daniel J. Jacob, J. William Munger, Bruce C. Daube, William C. Keene, John R. Maben, and Richard S. Artz. 1995. "Carboxylic Acids in the Rural Continental Atmosphere over the Eastern United States During the Shenandoah Cloud and Photochemistry Experiment." Journal of Geophysical Research 100 (D5): 9335. doi:10.1029/95jd00507.

\section{Published Version}

doi:10.1029/95JD00507

\section{Permanent link}

http://nrs.harvard.edu/urn-3:HUL.InstRepos:33490923

\section{Terms of Use}

This article was downloaded from Harvard University's DASH repository, and is made available under the terms and conditions applicable to Other Posted Material, as set forth at http:// nrs.harvard.edu/urn-3:HUL.InstRepos:dash.current.terms-of-use\#LAA

\section{Share Your Story}

The Harvard community has made this article openly available.

Please share how this access benefits you. Submit a story.

\section{Accessibility}




\title{
Carboxylic acids in the rural continental atmosphere over the eastern United States during the Shenandoah Cloud and Photochemistry Experiment
}

\author{
Robert W. Talbot, ${ }^{1}$ Byard W. Mosher, ${ }^{1}$ Brian G. Heikes, ${ }^{2}$ Daniel J. Jacob, ${ }^{3}$ \\ J. William Munger, ${ }^{3}$ Bruce C. Daube, ${ }^{3}$ William C. Keene, ${ }^{4}$ John R. Maben, ${ }^{4}$ \\ and Richard S. Artz
}

\begin{abstract}
The Shenandoah Cloud and Photochemistry Experiment (SCAPE) was conducted during September 1990 in the rural continental atmosphere at a mountain top site $(1014 \mathrm{~m})$ in Shenandoah National Park, Virginia. We report here the extensive set of trace gas measurements performed during clear sky periods of SCAPE, with particular focus on the carboxylic acids, formic, acetic, and pyruvic. Median mixing ratios were 5.4 and 2.1 parts per billion by volume (ppbv) for formic and acetic acid, respectively, and they did not exhibit the diurnal variation characteristic of low-elevation sites. Mixing ratios of formic acid often approached or exceeded $10 \mathrm{ppbv}$, which are the largest values yet reported for the nonurban troposphere. Over the rural eastern United States, formic and acetic acid appear to have significant nonphotochemical sources. Secondary production from suspected pathways appears to be relatively unimportant. The observed lack of correlation between formic and acetic acid with peroxide species argues against a significant source from permutation reactions of peroxy radicals. In addition, model calculations using the SCAPE data indicate minimal production of carboxylics from olefin/ $\mathrm{O}_{3}$ oxidation reactions. The tight correlation $\left(\mathrm{r}^{2}=0.88\right)$ between mixing ratios of formic and acetic acid is strongly suggestive of a commonality in their sources. The seasonal cycle of carboxylic acids in the atmosphere and precipitation over the eastern United States is evidence that combustion emissions are not a principal source of these species. It appears that direct biogenic emissions from vegetation and soils cannot be ruled out as important sources. In particular, the correlation between the seasonal variation of formic and acetic acid and the ambient temperature is consistent with a soil microbial source. Similar conclusions were reached for pyruvic acid, with its mixing ratio ranging 4 - 266 parts per trillion by volume (pptv) (median $=63$ ) and most likely supported by biogenic emissions and possibly photochemical sources.
\end{abstract}

\section{Introduction}

Formic $(\mathrm{HCOOH})$ and acetic $\left(\mathrm{CH}_{3} \mathrm{COOH}\right)$ acids are ubiquitous trace gases in the troposphere. They contribute between 16 and $35 \%$ of the free acidity in North American precipitation and up to $98 \%$ in remote areas [Keene and Galloway, 1984]. The presence of formic and acetic acids in the atmosphere influences $p \mathrm{H}$-dependent chemical reactions in clouds [Keene and Galloway, 1988]. Formic acid is also a major sink for OH radicals in cloudwater [Jacob, 1986].

\footnotetext{
${ }^{1}$ Institute for the Study of Earth, Oceans and Space, University of New Hampshire, Durham.

${ }^{2}$ Center for Atmospheric Chemistry, University of Rhode Island, Narragansett.

${ }^{3}$ Division of Applied Sciences, Department of Earth and Planetary Sciences, Harvard University, Cambridge, Massachusetts.

${ }^{4}$ Department of Environmental Sciences, University of Virginia, Charlottesville.

${ }^{5}$ Air Resources Laboratory, NOAA, Silver Spring, Maryland.
}

Copyright 1995 by the American Geophysical Union.

Paper number 95JD00507.

0148-0227/95/95JD-00507\$05.00
In the absence of cloud, less than $5 \%$ of atmospheric formic and acetic are in the condensed phase [Talbot et al., 1988].

General sources of carboxylic acids have been identified, but a satisfactory source attribution is lacking to explain atmospheric observations. Direct emissions from combustion in motor vehicles and biomass burning have been observed [Kawamura et al., 1985; Talbot et al., 1988; Hartmann, 1990]. Seasonal trends in the concentration of carboxylic acids in precipitation and the gas phase point to the biosphere, vegetation in particular, as a source of these species to the troposphere during the growing season [Keene and Galloway, 1986; Talbot et al., 1988]. Gas phase reaction of peroxy acetyl radicals with $\mathrm{HO}_{2}$ and organic peroxy radicals could represent a significant atmospheric source of acetic acid [Niki et al., 1985; Moortgat et al., 1989a, b; Madronich et al., 1990; Madronich and Calvert, 1990]. Formic acid may be produced by aqueous phase $\mathrm{OH}$ oxidation of hydrated formaldehyde $\left(\mathrm{H}_{2} \mathrm{C}(\mathrm{OH})_{2}\right)$ in cloudwater [Chameides and Davis, 1983; Jacob, 1986]. Aqueous phase production mechanisms of acetic acid appear to be quite slow and probably provide a negligible source of this species to the troposphere [Jacob and Wofsy, 1988b].

The carboxylic pair of formic and pyruvic acids should be produced proportionately (25-50:1) and in significant 
quantities by gas phase decomposition of isoprene [Jacob and Wofsy, 1988a, b]. Circumstantial evidence in support of this mechanism has been obtained through simultaneous measurements of gas phase formic and pyruvic acids in the atmosphere [Andreae et al., 1987; Talbot et al., 1990]. Recent smog chamber studies corroborate pyruvic acid as a minor decomposition product ( $\leq 5 \%$ yield) of isoprene [Grosjean et al., 1993].

In this paper we examine interrelationships of formic, acetic, and pyruvic acids with various atmospheric species and meteorological regimes at a mountain top site in Shenandoah National Park, Virginia. In September 1990 an intensive experiment was conducted at this site entitled "Shenandoah Cloud and Photochemistry Experiment (SCAPE)." A major objective of SCAPE was to examine in-cloud gas and aqueous phase chemical dynamics of selected carboxylic and carbonyl compounds. We utilize here the extensive set of gas phase measurements obtained during clear sky periods of SCAPE to examine source characteristics of selected carboxylics in the atmosphere over the eastern United States. For the purposes of this paper we utilize the term "clear sky" to characterize time periods where the sampling site was not engulfed incloud or receiving precipitation. Companion papers discuss data for ozone and related photochemistry [Jacob et al,, this issue], carbonyl compounds [Munger et al., this issue], and cloud effects on carboxylic acid concentrations [Keene et al., this issue].

\section{Experimental Methods}

\subsection{Site Description}

SCAPE measurements were conducted from a $15-\mathrm{m}$ tower located on a mountain ridge (elevation of $1014 \mathrm{~m}$ ) in the Shaver Hollow watershed in Shenandoah National Park (Pinnacles site). The watershed covers an area of approximately 223 ha and has an elevation range from 503 to 1037 $\mathrm{m}$. Second-growth oak and hickory hardwoods dominate the vegetation. The top of the forest canopy at the tower site is approximately $12 \mathrm{~m}$. The tower was installed at the site without removing any trees and the electrical lines leading to it were buried underground to keep the forest in its natural state. The tower was equipped with standard fastresponse meteorological instrumentation. These sensors supplied information for SCAPE on parameters such as wind speed and direction, barometric pressure, temperature, humidity, and solar radiation.

\subsection{Field Sampling}

The mist chamber technique was used to collect and concentrate gas phase carboxylic acids from the atmosphere [Talbot et al., 1988; Keene et al., 1989]. The mist chamber sampler was mounted on the tower at a location about $2 \mathrm{~m}$ above the forest canopy. Vacuum tubing was routed from the mist chamber to the base of the tower to a flowmeter/pumping assembly housed in a wooden shelter. Exhaust from the pump was directed away from the tower through $20 \mathrm{~m}$ of tubing. We utilized a Teledyne Hastings-Raydist linear mass flowmeter equipped with an integrating flow totalizer. Sampling flow rates were nominally 30 standard liters per minute. The accuracy of the determination of the sampled air volumes was $\pm 3 \%$. Sampling times were normally 1 hour, with occasionally shorter $(30 \mathrm{~min})$ or longer $(90 \mathrm{~min})$ periods used. Samples were stored in $30-\mathrm{mL}$ high-density amber polyethylene bottles. Immediately after collection, samples were spiked with $100 \mu \mathrm{L}$ of chloroform to minimize biological degradation of the carboxylic acids.

The mist chamber was cleaned prior to each sampling period by pulling ambient air through a cleaning train that consisted of two carbonate impregnated filters coupled to an activated charcoal cartridge. A $2-\mu \mathrm{m}$ pore-sized Zefluor Teflon filter was inline between the charcoal cartridge and the mist chamber to capture particles liberated from the cleaning assembly. The protocol we used generated blanks at the end of the cleaning period which simulated $30-\mathrm{min}$ ambient samples. The concentration of carboxylate species in the blank solutions was insignificant.

Ozone $\left(\mathrm{O}_{3}\right)$, nitric oxide (NO), total reactive nitrogen $\left(\mathrm{NO}_{\mathrm{y}}\right)$, and carbon monoxide $(\mathrm{CO})$ were measured continuously (1-min time resolution) using instrumentation described by Poulida et al. [1991] and Doddridge et al. [1992]. Gas phase hydrogen peroxide $\left(\mathrm{H}_{2} \mathrm{O}_{2}\right)$ and organic hydroperoxides (ROOH) were measured with 5-min time resolution using an enzymatic technique [Heikes et al., 1992].

\subsection{Carboxylic Acid Chemical Analysis}

Mist chamber samples were analyzed for formate, acetate, and pyruvate using ion chromatography. We utilized a Dionex AS4 column with a $0.4-\mathrm{mmol} \mathrm{L}^{-1} \mathrm{NaHCO}_{3}$ eluent and $25-\mathrm{mmol} \mathrm{L}^{-1} \mathrm{H}_{2} \mathrm{SO}_{4}$ suppressor regenerant solution. Standards were prepared using anhydrous salts of the species of interest here. Standard solutions were exchanged with the University of Virginia group to verify our calibrations. Agreement was $\pm 5 \%$ for the exchanged carboxylic acid standards (concentrations ranged from 0.10 to $5.0 \mu \mathrm{mol} \mathrm{L}^{-1}$ ). The precision error of the chromatographic analysis was 3$5 \%$. Estimated analytical detection limits were $0.02 \mu \mathrm{mol} \mathrm{L}^{-1}$ for formate, $0.05 \mu \mathrm{mol} \mathrm{L}^{-1}$ for acetate, and $0.1 \mu \mathrm{mol} \mathrm{L}^{-1}$ for pyruvate. Propagation of error analysis indicated that the overall uncertainty in the gas phase mixing ratios was 10 $15 \%$. Atmospheric detection limits for a 60 -min sampling interval were 5,10 , and 20 parts per trillion by volume (pptv) for formic, acetic, and pyruvic acids, respectively.

\section{Results and Discussion}

\subsection{Time Series Trends}

Values for the mixing ratio of carbon monoxide, ozone, nitric oxide, and total reactive nitrogen were obtained by averaging the 1-min data for these species over the carboxylic acid sampling intervals. A summary of the descriptive statistics for trace gas mixing ratios during SCAPE is presented in Table 1. For comparison, values are also included for the mixing ratios of carbon monoxide, ozone, nitric oxide, and total reactive nitrogen observed at the nearby Big Meadows site in Shenandoah National Park during 1988-1989. These data were obtained with a portable instrumented (van) laboratory (equipped by R. R. Dickerson, University of Maryland; Poulida et al. [1991]; and Doddridge et al. [1992]). During SCAPE the van instruments were operated by B. G. Heikes.

Mixing ratios of carbon monoxide, nitric oxide (restricted to $1000-1400$ LT only), and total reactive nitrogen that correspond to the carboxylic acid measurement periods were quite comparable to their overall monthly mean value (or median) during SCAPE and also to such observations made in the park previously [Poulida et al., 1991; Doddridge et al., 1992] (Table 1). These observations together suggest 
that the SCAPE carboxylic acid measurements probably represent a good regional picture of these species in the atmosphere at this rural continental location.

The mean mixing ratio of 52 parts per billion by volume (ppbv) for ozone during the SCAPE clear sky, carboxylic acid measurement intervals (Table 1) was closer to its mean value in summertime (41 ppbv) rather than in fall at this site (31 ppbv) [Poulida et al., 1991]. In addition, the ratio nitric oxide/total reactive nitrogen was typically $<0.05$. These observations indicate that the carboxylic acid data were obtained in photochemically aged air masses. Four episodes of air mass stagnation occurred during SCAPE [Jacob et al., this issue], and two of these were captured during diurnal measurement periods for the carboxylic acids. These episodes occurred on the trailing end of anticyclones, indicative of regional-scale pollution events [Logan, 1989]. A companion paper discusses the details of ozone photochemistry during these time periods of SCAPE [Jacob et al., this issue].

Carboxylic acids were sampled intensively during several distinct intervals between September 6 (Julian day 249) and September 30 (Julian day 274, Figure 1). Cloud events occurred on September 8-9, 13-14, 20, 22, and 30. Measurable precipitation occurred at the site on September 8, 9, 12, $13,19,21,22$, and 30 . A total of 14 sequential precipitation samples (about one hour apart) were collected during these events [Keene et al., this issue]. The most notable event occurred on September 13 (Julian day 256) where approximately $6 \mathrm{~cm}$ of rain fell. The other individual events during SCAPE totaled $<1 \mathrm{~cm}$. Gas phase mixing ratios of the carboxylic acids were at their lowest values during the days immediately after these cloud or precipitation events (Figure 1). The details of chemical dynamics and transformations during these events are described by Keene et al., [this issue].

The mixing ratio of formic acid was usually significantly larger than that of acetic acid. During certain intervals the mixing ratio of formic acid exceeded $10 \mathrm{ppbv}$, which are the largest values reported to date for the rural continental atmosphere. Grosjean [1989] reported maximum mixing ratios for formic and acetic acids of 13 and $16 \mathrm{ppbv}$, respectively, for the southern California urban-air basin. To the best of our knowledge the only other reported occurrence of such large mixing ratios for formic and acetic acids is over southcentral Africa. Photochemically aged biomass burning plumes at 2-5 altitude had mixing ratios up to $15 \mathrm{ppbv}$ for these carboxylic species [Helas et al., 1992].

Mixing ratios of acetic acid during SCAPE did not reach values comparable to those for formic acid (i.e., $10 \mathrm{ppbv}$ or more). Collectively, the carboxylic acids appear to represent about $10 \mathrm{ppbv}$ of carbon in the atmosphere over the eastern United States. These two primary carboxylic acids thus appear to represent a significant pool of atmospheric carbon, but one of relatively low reactivity.

Two diurnal studies were conducted during SCAPE, consisting of continuous measurements of carboxylic acids for 30 hours. We did not observe the diurnal cycle in mixing ratio that typically occurs at lower elevations [Talbot et al., 1988]. Lower-elevation sites often exhibit nighttime depletion of carboxylic acids, presumably by efficient dry deposition from a shallow surface layer [Andreae et al., 1987; Jacob and Wofsy, 1988a, b; Talbot et al., 1988; Talbot et al., 1990]. Since upper boundary layer air does not directly interact with the surface, it is not subject to rapid

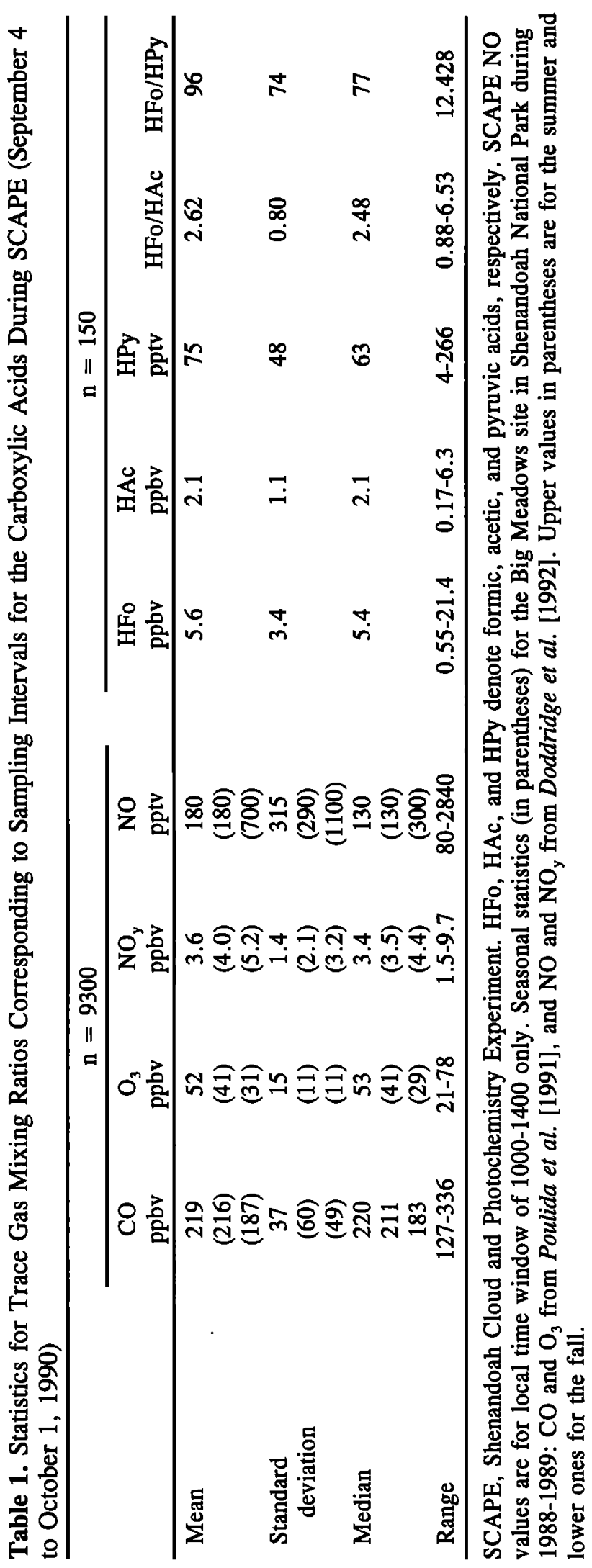




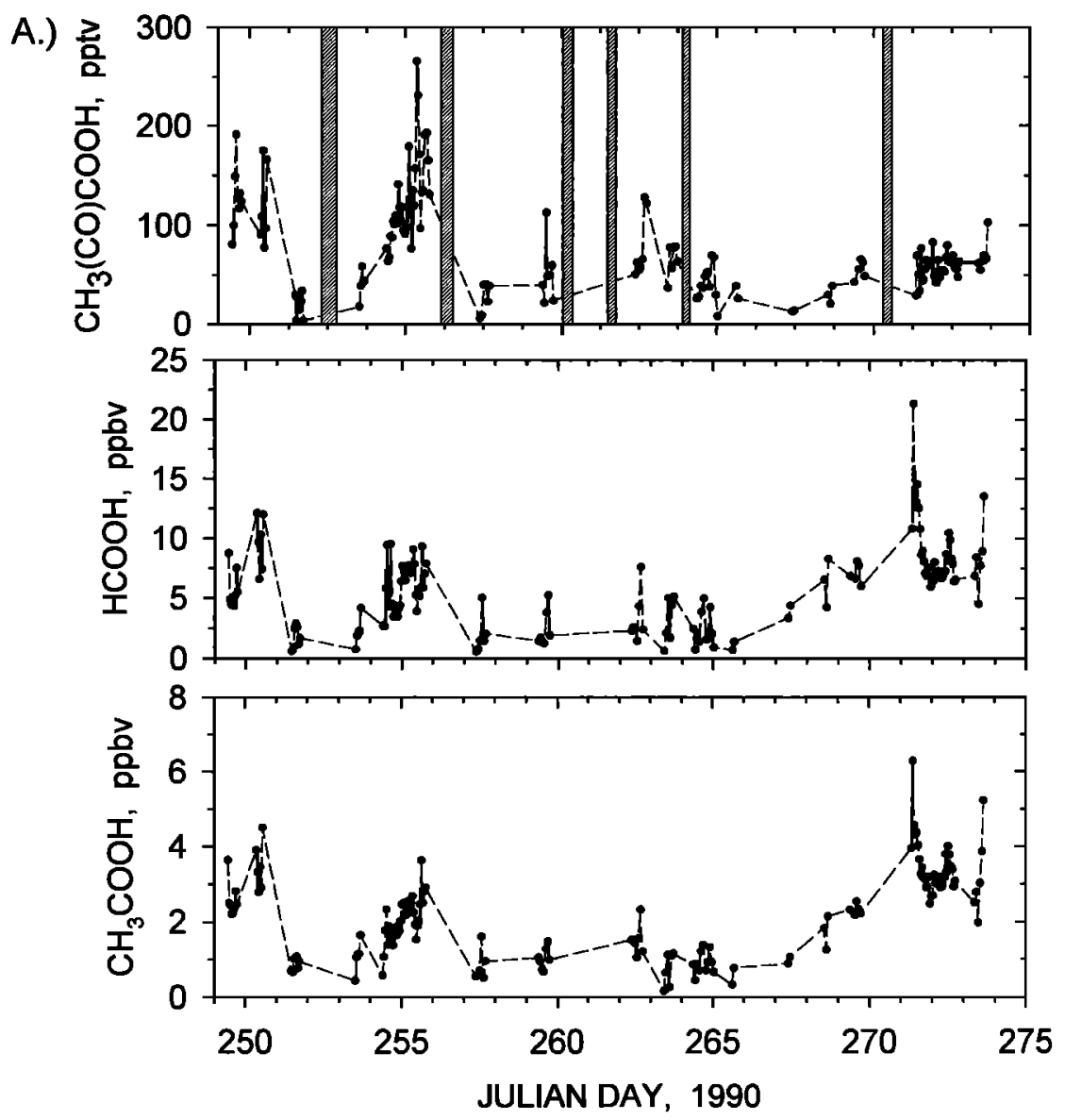

B.)
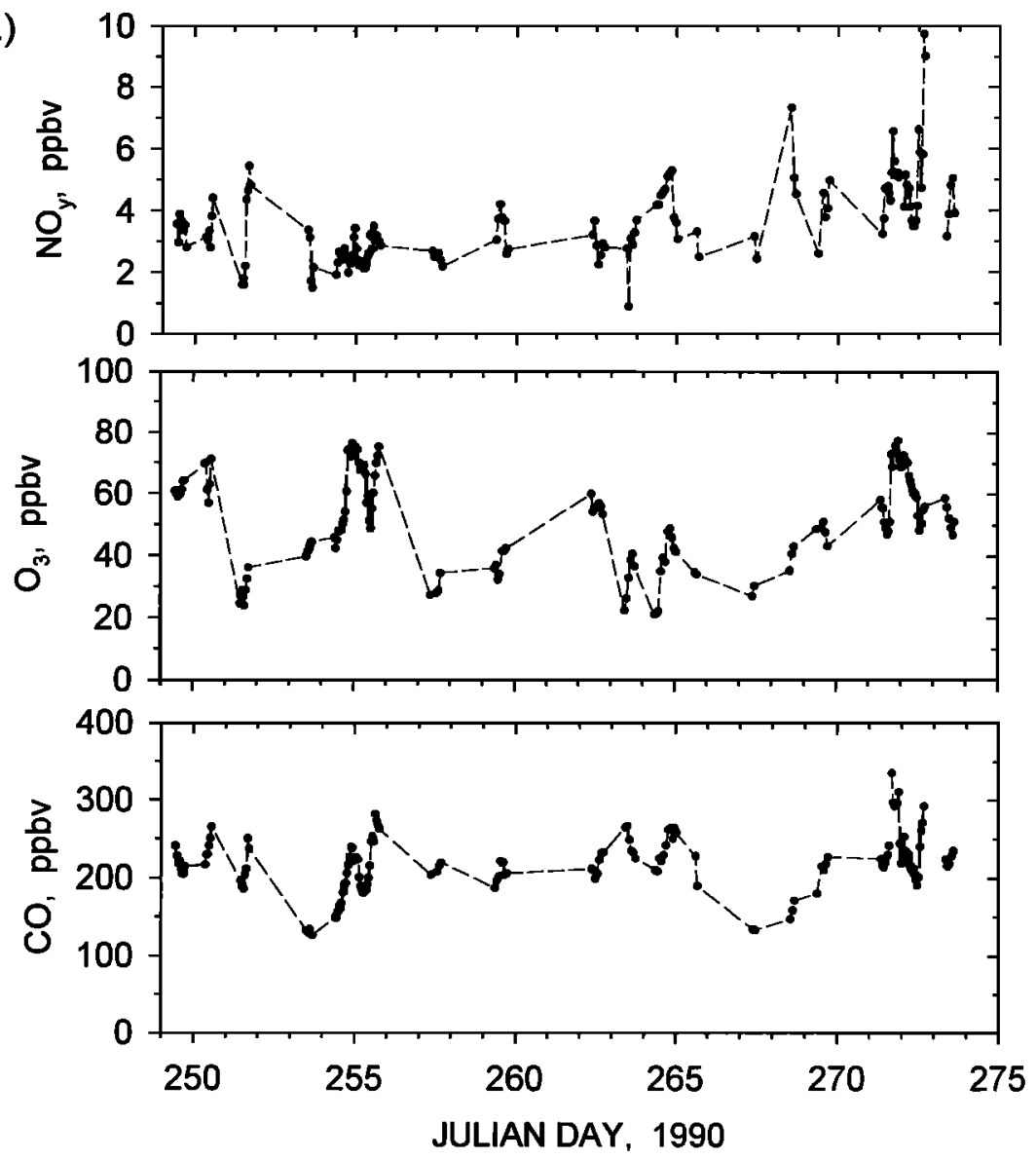

Figure 1. Time series of mixing ratios of (a) carboxylic acid, (b) carbon monoxide, ozone, and total reactive nitrogen during selected clear sky periods of September 1990. The shaded areas in the top plot indicate periods of precipitation or cloud events. 

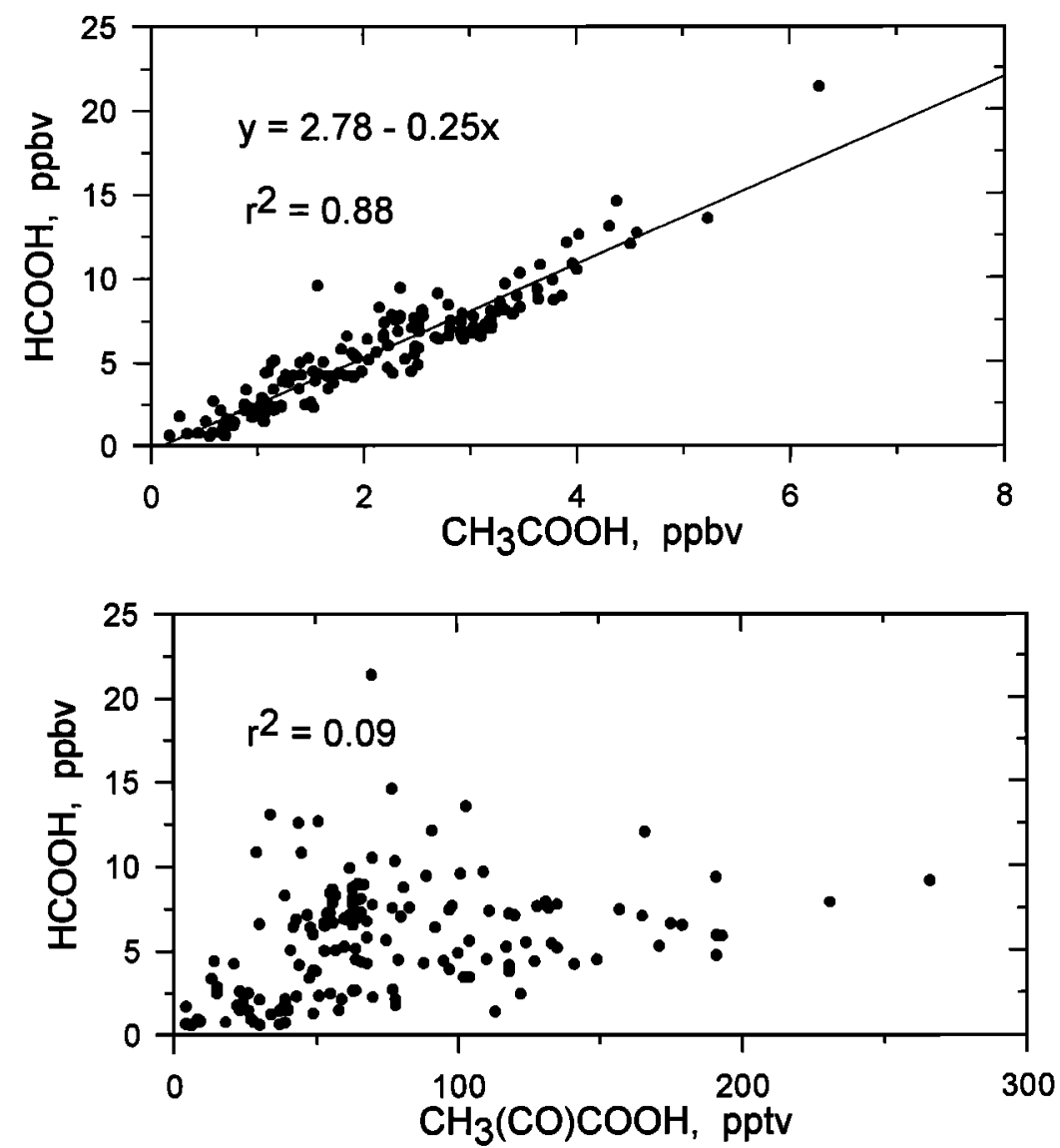

Figure 2. Relationship of formic with acetic or pyruvic acid mixing ratios during selected clear sky periods of Sepember 1990.

depletion of reactive gases by dry deposition. This feature is commonly observed for $\mathrm{O}_{3}$ at mountain top sites [Aneja et al., 1991]. With a mean boundary layer depth of $1.6 \mathrm{~km}$ in September [Holzworth, 1967] the supply of boundary layer air rich in trace gases appears to more than compensate for losses by dry deposition to this mountain top site.

\subsection{Interspecies Relationships}

3.2.1. Between carboxylic acids. Values of the ratio formic/acetic (Figure 2) were on the average (Table 1) similar to those observed in late summer at a coastal Virginia site during 1985-1986 [Talbot et al., 1988]. A reduced major axis regression for the SCAPE data indicated the following linear relationship between mixing ratios of formic and acetic acid: $y=2.78 x-0.26$, with $r^{2}=0.88$. This relationship agrees remarkably well with that observed previously for these two species in growing season precipitation at this site $\left(\mathrm{y}=2.62 \mathrm{x}-0.24\right.$, with $\mathrm{r}^{2}=0.95$ [Keene and Galloway, 1986]). The 14 precipitation samples collected during SCAPE yielded a relationship of $y=2.47 \mathrm{x}$ 5.56. The significantly larger value of the intercept for these data is driven mainly by one sample which exhibited an anomalously enhanced formic/acetic ratio value (and a rather small sample volume). Ignoring this one value reduced the intercept to -0.36 , which indicates remarkable agreement in the value of the slopes for all of these various linear relationships.

The mixing ratios of pyruvic acid during SCAPE were similar to those observed during summertime in central
Virginia and the dry season in the Amazon Basin, Brazil [Andreae et al., 1987]. Values of the ratio formic/pyruvic (Figure 2) were, however, among the largest observed thus far and were, in general, significantly greater than those expected from an isoprene oxidation source [Jacob and Wofsy, 1988b]. A reduced major axis regression of formic and pyruvic acid mixing ratios showed poor linear relationship $\left(r^{2}=0.09\right)$, emphasizing the potential importance of nonisoprene-related sources for formic acid. However, this does not rule out the possibility of a principal isoprene source for pyruvic acid.

3.2.2. With other trace gases. Mixing ratios of formic, acetic, and pyruvic acids were compared with those of several trace gases measured during SCAPE. Few significant $(p=0.05)$ linear correlations were identified. There was generally poor correlation $\left(\mathrm{r}^{2}<0.5\right)$ with carbon monoxide, nitric oxide (daytime only), and total reactive nitrogen. Unambiguous relationships between carboxylic acids and anthropogenic species are likely often obscured in the rural continental atmosphere due to influence from wet and dry depositional processes and variation in source emissions. Contributions of carboxylic acids from natural biogenic emissions also confound the issue. This same lack of correlation of formic and acetic acids with other trace species (e.g., carbon monoxide and total reactive nitrogen) has also been observed for aged free tropospheric (marine) air sampled under downslope flow conditions at Mauna Loa, Hawaii [Norton, 1992]. 

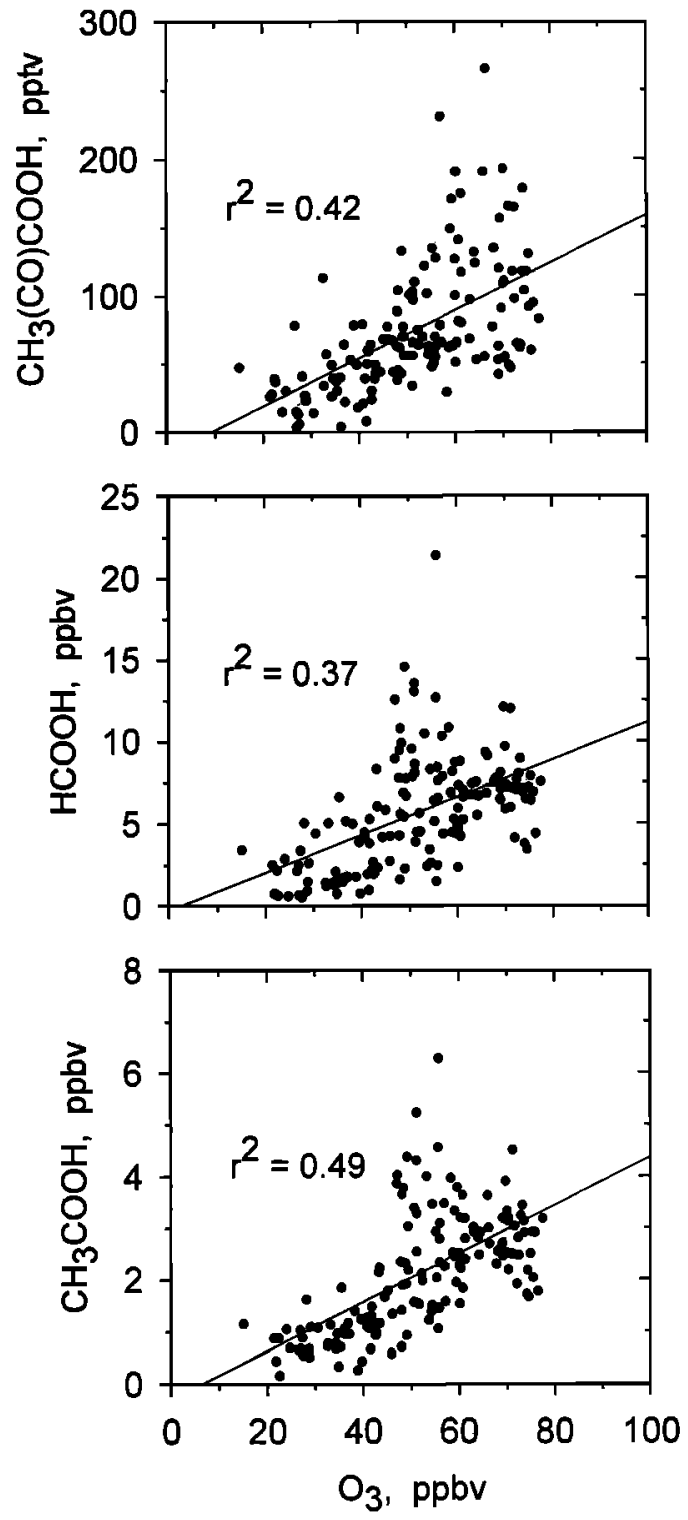

Figure 3. Relationship between mixing ratios of formic, acetic, and pyruvic acids with ozone.

Theoretical calculations indicate that carboxylic acids should be produced in the gas phase by various photochemical mechanisms [Jacob and Wofsy, 1988a, b; Madronich et al., 1990]. Correlations between carboxylic acids and known photochemical product species should therefore be evident in aged continental air masses not altered significantly by wet and dry deposition processes.

We examined the SCAPE data for general relationship of formic, acetic, and pyruvic acids with ozone, a principal photochemical product. Enhanced mixing ratios of ozone may lead to carboxylic acid production through various decomposition reactions with alkenes. The various carboxylic-ozone relationships are shown in Figure 3. Overall, the correlations are reasonably strong $\left(r^{2} \approx 0.5\right)$ and they are improved if the few largest mixing ratio values for each carboxylic acid are ignored $\left(r^{2} \approx 0.7\right)$.

Peroxide compounds are other important indicators of photochemical processes [Heikes, 1992]. During SCAPE, peroxide mixing ratios decreased significantly after
mid-September as solar radiation intensity decreased [Jacob et al., this issue]. Such a trend was not observed for formic and acetic acids, as they were present at some of their largest mixing ratios during the latter half of September (Figure 1). In addition, there were no significant linear correlations of formic and acetic acids with hydrogen peroxide or organic hydroperoxides (Figure 4). We thus find no clear evidence for predominance of photochemical production of formic and acetic acids from peroxy radical combination reactions similar to those producing peroxide species.

A different picture emerged for pyruvic acid (Figure 4). Although there was poor correlation of mixing ratios of pyruvic acid with those of hydrogen peroxide, there was significant linear relationship between pyruvic acid and organic hydroperoxides. Ignoring the two largest mixing ratio values above $200 \mathrm{pptv}, \mathrm{r}^{2}=0.66$ for correlation between pyruvic and organic hydroperoxides. Furthermore, the September temporal time series of pyruvic acid mixing ratios (Figure 1) exhibited a trend analogous to that of the peroxides, with decreased values in the latter half of the month [Jacob et al., this issue]. Mixing ratios of pyruvic acid rarely exceeded 100 pptv after mid-September, contrasting values up to about 300 pptv earlier in the month. The decreased peroxide mixing ratios from mid-September on appear to reflect a seasonal shift in the photochemical regime from nitrogen-oxide limited $\left[\mathrm{NO}_{\mathrm{x}}=\right.$ (NO plus nitrogen dioxide $\left(\mathrm{NO}_{2}\right)$ ] to hydrocarbon-limited [Jacob et al., this issue]. The trend in pyruvic acid may reflect the slowing in biogenic emissions near the end of the growing season.

\subsection{Implications for Sources of Carboxylic Acids}

The SCAPE data provided circumstantial evidence that biogenic hydrocarbon emissions decreased sharply in the time span going from early to late September as the end of the annual midlatitude growing season approached. An argument for this is in the photochemistry, as it appears to be hydrocarbon-limited during the latter half of September [Jacob et al., this issue]. Many of the air masses arriving at the Pinnacles site also originated from more northerly latitudes where the vegetation was already undergoing senescence. Continuous measurements of isoprene above the Harvard Forest canopy in Petersham, Massachusetts, show that the biosphere essentially ceases atmospheric emissions of isoprene in mid-September [Goldstein, 1994]. Carboxylic acid concentrations in rainwater also show a dramatic decrease at this time of the year [Keene and Galloway, 1986].

Mixing ratios of formic and acetic acid did not exhibit a decreasing trend during September as pyruvic acid did (Figure 1). We interpret this observation as evidence for a nonbiogenic source contribution of these species. The seasonal trend of carboxylic acid concentrations in precipitation at this site suggests that they also have significant biogenic sources during the growing season [Keene and Galloway, 1984, 1988]. Direct emission of carboxylic acids from vegetation and soils in the tropics has been documented [Talbot et al., 1990; Sanhueza and Andreae, 1991], which raises the possibility that such release also occurs at midlatitude sites.

The source of carboxylic acids from atmospheric oxidation of hydrocarbons was assessed using a one-dimensional model for the boundary layer over the eastern United States 

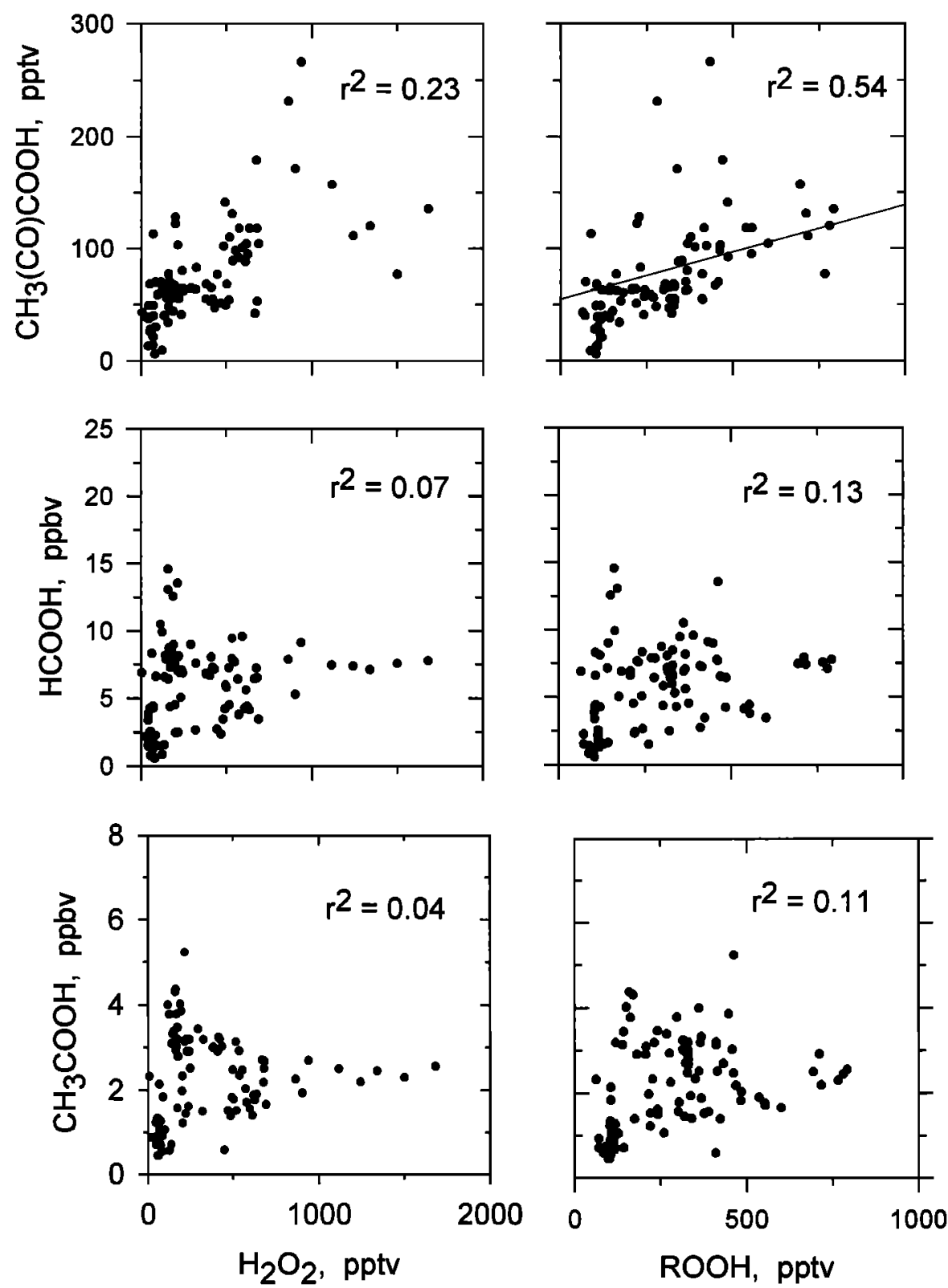

Figure 4. Relationhship between mixing ratios of formic, acetic, and pyruvic acids with those of hydrogen peroxide and organic hydroperoxides.

in September [Jacob et al., this issue; Munger et al., this issue]. The model includes mean anthropogenic 24-hour emission fluxes of $\mathrm{C}_{2-7}$ alkanes and $\mathrm{C}_{2-4}$ alkenes from the region, as given by McKeen et al. [1991], and a 24-hour average isoprene emission flux of $5 \times 10^{10}$ molecules $\mathrm{cm}^{-2} \mathrm{~s}^{-1}$ designed to match the SCAPE carbonyl data [Munger et al., this issue]. Diel mean sources of carboxylic acid computed in the model boundary layer $(0-1.6 \mathrm{~km})$ were $27 \mathrm{pptv} \mathrm{d}^{-1}$ for formic acid (mainly ozonolysis of isoprene and alkenes), 140 pptv d ${ }^{-1}$ for acetic acid $\left(\mathrm{CH}_{3} \mathrm{CO}_{3}+\right.$ peroxy reactions, where the $\mathrm{CH}_{3} \mathrm{CO}_{3}$ radicals originate mainly from oxidation of alkanes and isoprene), and $1.7 \mathrm{pptv} \mathrm{d}^{-1}$ for pyruvic acid (ozonolysis of isoprene). Considering that the lifetimes of formic and acetic acids against deposition in the boundary layer are probably of the order of a few days and that the model lifetime of pyruvic acid against photolysis is 11 hours
[Grosjean, 1983], we conclude that known hydrocarbon oxidation pathways cannot account for the mixing ratios of carboxylic acids observed during SCAPE.

Air mass trajectories calculated for the SCAPE study period showed that about $25 \%$ of the time air was sampled that several days earlier had been at $700-800 \mathrm{hPa}(3-5 \mathrm{~km})$ altitude over the Hudson Bay lowlands region of central Canada. Biomass burning emissions over this area are known to be rich in formic and acetic acids [Lefer et al., 1994]. Our analysis of the SCAPE data did not reveal unambiguous correlations between air masses originating over the Hudson Bay lowlands region and subsequent enhancement of carboxylic acid mixing ratios at the Pinnacles site. This analysis was complicated by the fact that the air masses originating in Canada also passed over major industrial areas of the middle or eastern United States before 
arriving at our sampling site. Since air masses from this Canadian region only reached our site during three multiday episodes during SCAPE, it is unlikely that the relatively large average mixing ratio of carboxylic acids can be attributed to long-range transport inputs of biomass burning emissions.

Previous model calculations suggest that oxidation of isoprene by ozone might lead to production of formic, methacrylic $\left[\mathrm{H}_{2} \mathrm{CC}\left(\mathrm{CH}_{3}\right) \mathrm{COOH}\right]$, and pyruvic acids [Jacob and Wofsy, 1988b]. Mixing ratios of pyruvic acid during SCAPE were in a range that could be reasonably supported by direct and secondary biogenic emissions. We never observed, however, even trace amounts of methacrylic acid in our mist chamber samples. Recent smog chamber studies [Grosjean et al., 1993] also indicate that methacrylic acid is probably not formed during isoprene decomposition in the atmosphere.

Significant emission of formic and acetic acid is known to occur from tropical savanna soils [Sanhueza and Andreae, 1991]. These emissions exhibit a diurnal cycle that peaks at midday. The conclusions reached here from the SCAPE data regarding secondary production of carboxylic acids in the atmosphere suggest that soils should be considered as a potential and possibly substantial source of carboyxlic acids in midlatitude regions. The correlation between the seasonal variation of formic and acetic acids and the ambient temperature observed by Talbot et al. [1988] is consistent with a soil microbial source. If the soil emissions followed a diurnal cycle like the one observed in the tropics, this would explain the apparently large daytime source of atmospheric carboxylic acids. In addition, direct vegetative emissions may also be significant and they should have patterns consistent with observed variations of atmospheric carboxylic acids. It appears that an emission inventory of carboxylic acid fluxes from natural sources would provide timely information.

\section{Conclusions}

The SCAPE clear sky data set provided a unique suite of measurements of important tropospheric trace gases in a rural continental environment influenced by interaction of natural biogenic with photochemically aged anthropogenic emissions. Because of its $1000-\mathrm{m}$ height, mixing ratios of trace gases at the Pinnacles site do not exhibit diurnal cycles typical of low-elevation locations. The supply of boundary layer air rich in trace gases appears to more than compensate for losses by dry deposition.

The SCAPE clear air data provide important new constraints on the sources of atmospheric formic and acetic acid in the midlatitude continental atmosphere. It is unlikely that decomposition of isoprene or other nonmethane hydrocarbons can be a dominant source of these acids. The poor correlations between mixing ratios of formic and acetic acid and those of other trace gases suggest that these species have complex source signatures. However, formic and acetic acid are themselves highly correlated both here and at other sites around the world, indicating that their atmospheric concentrations are controlled by similar processes. Previously published precipitation data for the Pinnacles site indicates that formic and acetic acid have important biogenic sources during the growing season. Our analysis here suggests that this is probably due to direct emission from vegetation and soils. Although carboxylic acids are known to be present in anthropogenic and biomass burning emissions, their poor correlation with combustion-related species such as carbon monoxide and total reactive nitrogen implies that these sources were not dominant at this site.

Acknowledgments. Support from the MCCP, especially John Sigmon and Patricia Thompson, provided valuable assistance and meteorological measurements for successful execution of this work. We appreciate the hospitality of the National Park Service and the coordination by Richard Potts for on-site housing and laboratory space. Many thanks to all the SCAPE participants for an enjoyable and successful field experiment. The National Science Foundation provided financial support for this study through grants to the University of New Hampshire (ATM-8912156), the University of Rhode Island (ATM9015769), Harvard University (ATM-8812157), and the University of Virginia (ATM-8911815). In addition, URI acknowledges the Electric Power Research Institute (contract RP-2023-12) for support of the peroxide measurements, Robert Arnst of the U.S. Environmental Protection Agency for facilitating the loan of the van instrumentation, and Meehye Lee for her efforts in conducting the peroxide and nitrogen oxide measurements. Larry W. Horowitz (Harvard) performed the photochemical model calculations.

\section{References}

Andreae, M. O., R. W. Talbot, and S.-M. Li, Atmospheric measurements of pyruvic and formic acid, J. Geophys. Res., 92, 6635-6641, 1987.

Aneja, V. P., S. Businger, Z. Li, C. S. Claiborn, and A.Murphy, Ozone climatology at high elevations in the southern Appalachians, J. Geophys. Res., 96, 1007-1021, 1991.

Chameides, W. L., and D. D. Davis, Aqueous-phase source of formic acid in clouds, Nature, 304, 427-429, 1983.

Doddridge, B. G., R. R. Dickerson, R. G. Wardell, K. L. Civerolo, and L. J. Nunnermacker, Trace gas concentrations and meteorology in rural Virginia, 2, Reactive nitrogen compounds, J. Geophys. Res., 97, 20,631-20,646, 1992.

Goldstein, A. H., Non-methane hydrocarbons above a midlatitude forest: Biogenic emissions and seasonal concentration variations, Ph.D. thesis, Harvard Univ., Cambridge, Mass., 1994.

Grosjean, D., Atmospheric reactions of pyruvic acid, Atmos. Environ., 17, 2379-2382, 1983.

Grosjean, D., Organic acids in southern California air: Ambient concentrations, mobile source emissions, in situ formation and removal processes, Environ. Sci. Technol., 23, 1506-1514, 1989.

Grosjean, D., E. L. Williams, and E. Grosjean, Atmospheric chemistry of isoprene and of its carbonyl products, Environ. Sci. Technol., 27, 830-840, 1993.

Hartmann, W. R., Carbonsauer in der Atmosphäre, Ph.D. thesis, 106 pp., Univ. of Mainz, Germany, 1990.

Heikes, B. G., Formaldehyde and hydroperoxides at Mauna Loa Observatory, J. Geophys. Res., 97, 18,001-18,013, 1992.

Helas, G., H. Bingemer, and M. O. Andreae, Organic acids over equatorial Africa: Results from DECAFE 88, J. Geophys. Res., 97, 6187-6193, 1992.

Holzworth, G. C., Mixing depths, wind speeds and air pollu tion potentials for selected locations in the United States, $J$. Appl. Meteor., 6, 1039-1044, 1967.

Jacob, D. J., Chemistry of $\mathrm{OH}$ in remote clouds and its role in the production of formic acid and peroxymonosulfate, $J$. Geophys. Res., 91, 9807-9826, 1986. 
Jacob, D. J., and S. C. Wofsy, Photochemistry of biogenic emissions over the Amazon forest, J. Geophys. Res., 93, 1477-1486, 1988a.

Jacob, D. J., and S. C. Wofsy, Photochemical production of carboxylic acids in a remote continental atmosphere, in Acid Deposition Processes at High Elevation Sites, edited by M. H. Unsworth, pp. 73-92, D. Reidel, Highham, Mass., $1988 b$.

Jacob, D. J., L. W. Horowitz, J. W. Munger, B. G. Heikes, R. R. Dickerson, R. S. Artz, and W. C. Keene, Seasonal transition from $\mathrm{NO}_{x}$ - to hydrocarbon-limited conditions for ozone production over the eastern United States, J. Geophys. Res., this issue.

Kawamura, K., L.-L. Ng, and I. R. Kaplan, Determination of organic acids $\left(\mathrm{C}_{1}-\mathrm{C}_{10}\right)$ in the atmosphere, motor exhausts, and engine oils, Environ. Sci. Technol., 19, 1082-1086, 1985.

Keene, W. C., and J. N. Galloway, Organic acidity in precipitation of North America, Atmos. Environ., 18, 2491-2497, 1984.

Keene, W. C., and J. N. Galloway, Considerations regarding sources for formic and acetic acids in the troposphere, $J$. Geophys. Res., 91, 14,466-14,474, 1986.

Keene, W. C., and J. N. Galloway, The biogeochemical cycling of formic and acetic acids through the troposphere: An overview of current understanding, Tellus, 40 (B), 322 $334,1988$.

Keene, W. C., et al., An intercomparison of measurement systems for vapor and particulate concentrations of formic and acetic acids, J. Geophys. Res., 94, 6457-6471, 1989.

Keene, W. C., B. W. Mosher, D. J. Jacob, J. W. Munger, R. W. Talbot, R. S. Artz, J. M. Maben, B. C. Daube, and J. N. Galloway, Carboxylic acids in clouds at a high-elevation forested site in central Virginia, J. Geophys. Res., this issue.

Lefer, B. L., et al., Enhancement of acidic gases in biomassburning impacted air masses over Canada, J. Geophys. Res., 99, 1721-1737, 1994.

Logan, J. A., Ozone in rural areas of the United States, J. Geophys. Res., 94, 8511-8532, 1989.

Madronich, S., and J. G. Calvert, Permutation reactions of organic peroxy radicals in the troposphere, J. Geophys. Res., 95, 5697-5717, 1990.

Madronich, S., R. B Chatfield, J. G. Calvert, G. K. Moortgat, B. Veyret, and R. Lesclaux, A photochemical origin of acetic acid in the troposphere, Geophys. Res. Lett., 17, 2361-2364, 1990.

McKeen, S. A., E.-Y. Hsie, M. Trainer, R. Tallamraju, and S. C. Liu, A regional model study of the ozone budget in the eastern United States, J. Geophys. Res., 96, 10,809-10,845, 1991.
Moortgat, G., B. Veyret, and R. Lesclaux, Absorption spec trum and kinetics of reactions of the acetylperoxy radical, $J$. Phys. Chem., 93, 2362-2368, 1989a.

Moortgat, G., B. Veyret, and R. Lesclaux, Kinetics of the reaction of $\mathrm{HO}_{2}$ with $\mathrm{CH}_{3} \mathrm{C}(\mathrm{O}) \mathrm{O}_{2}$ in the temperature range 253-368 K, Chem. Phys. Lett., 160, 443-447, $1989 \mathrm{~b}$.

Munger, J. W., D. J. Jacob, B. C. Daube, L. W. Horowitz, W. C. Keene, and B. G. Heikes, Formaldehyde, glyoxal, and methylglyoxal in air and cloudwater at a rural mountain site in central Virginia, J. Geophys. Res., this issue.

Niki, H., P. D. Maker, C. M. Savage, and L. P. Breitenbach, FTIR study of kinetics and mechanism for $\mathrm{Cl}$-atom-initiated reactions of acetaldehyde, J. Phys. Chem., 89, 588-591, 1985.

Norton, R. B., Measurements of gas phase formic and acetic acids at the Mauna Loa, Observatory, Hawaii, during the Mauna Loa Observatory Photochemical Experiment 1988, $J$. Geophys. Res., 97, 10,389-10,393, 1992.

Poulida, O., R. R. Dickerson, B. G. Doddridge, J. Z. Holland, R. G. Wardell, and J. G. Watkins, Trace gas concentrations and meteorology in rural Virginia, 1 , Ozone and carbon monoxide, J. Geophys. Res., 96, 22,461-22, 475, 1991.

Sanhueza, E., and M. O. Andreae, Emission of formic and acetic acids from tropical savanna soils, Geophys. Res. Lett., $18,1707-1710,1991$

Talbot, R. W., K. M. Beecher, R. C. Harriss, and W. R. Cofer III, Atmospheric geochemistry of formic and acetic acids at a midlatitude temperate site, J. Geophys. Res., 93, 1638-1652, 1988.

Talbot, R. W., M. O. Andreae, H. Berresheim, D. J. Jacob, and $\mathrm{K}$. M. Beecher, Sources and sinks of formic, acetic, and pyruvic acids over central Amazonia, 2, Wet season, $J$. Geophys. Res., 95, 16-799-16,811, 1990.

R. S. Artz, Air Resources Laboratory, NOAA, Silver Spring, MD 20910.

B. C. Daube, D. J. Jacob, and J. W. Munger, Division of Applied Sciences, Department of Earth and Planetary Sciences, Pierce Hall, Harvard University, Cambridge, MA 02138.

B. G. Heikes, Center for Atmospheric Chemistry, University of Rhode Island, Narragansett, RI 02882.

W. C. Keene and J. R. Maben, Department of Environmental Sciences, Clark Hall, University of Virginia, Charlottesville, VA 22903.

B. W. Mosher and R. W. Talbot (corresponding author), Institute for the Study of Earth, Oceans and Space, Morse Hall, University of New Hampshire, Durham, NH 03824. (e-mail: rwt@christa.unh.edu)

(Received January 18, 1994; revised February 7, 1995; accepted February 12, 1995.) 